DOI: $10.29303 / \mathrm{jrpb} . \mathrm{v} 9 \mathrm{i} 1.236$

ISSN 2301-8119, e-ISSN 2443-1354

Tersedia online di http://jrpb.unram.ac.id/

\title{
PENENTUAN DAYA DUKUNG LINGKUNGAN BERBASIS NERACA LAHAN DI KECAMATAN PRAYA BARAT
}

\author{
Determination of Environmental Carrying Capacity Based on Land's Balance \\ at West Praya Subdistrict
}

\section{Lalu Heri Rizaldi*), Bambang Rahadi, Evi Kurniati}

\author{
Program Studi Teknik Pertanian, Fakultas Teknologi Pertanian, Universitas Brawijaya \\ Jl. Veteran, Malang 65145, Indonesia \\ Email$^{*}$ : rizaldilaluheri@gmail.com \\ Diterima: November 2020 \\ Disetujui: 2021
}

\begin{abstract}
The human population is increasing, causing increased needs for food and shelter. Therefore a balance is needed between the carrying capacity of the environment and the land use existing. The research aims to determine the environmental carrying capacity status based on the existing land balance and determine the land balance status in 2031, using quantitative descriptive methods by describing the calculations' results to obtain land balance status. The calculation of land's availability and requirement was projected to evaluate the supply and demand for land in 2031. The simulation process is made by projecting the population until 2031 using arithmetic. The result of the supply and demand of land compared to getting the balance status of the land. West Praya Subdistrict has a total production value of Rp $3,965,659,613,333.34$, rice productivity $3251 \mathrm{Kg} / \mathrm{Ha}$; with the price of rice is $\mathrm{Rp} 8000 \mathrm{Kg}$, the result shows that the availability of existing land is 152,478.03 Ha. Analysis of land requirement shows that the total value of existing needs is $23120.82 \mathrm{Ha}$, the population in 2018 is 75166 people, and the need for decent living (KHL) is $0.31 \mathrm{Ha}$ capita. The status of the existing land balance in West Praya Subdistrict is surplus, with a difference of 129,357.21 Ha. Calculation of the environmental carrying capacity of the basis of land balance in 2031 uses the existing land availability, namely 152,478.03 $\mathrm{Ha}$, while the calculation of land needs using the population ( $N$ ) in 2031 is 88,285 people. 2031 obtained land requirement of 27,156.04 ha. The status of the land balance carrying capacity of West Praya Subdistrict in 2031 is still a surplus. The difference is 125,321.99 Ha. The surplus status shows the availability of land to meet the needs of the local community's biological products.
\end{abstract}

Keywords: environmental carrying capacity; land balance

\begin{abstract}
ABSTRAK
Populasi manusia yang semakin meningkat menyebabkan bertambahnya kebutuhan pangan dan tempat tinggal, karena itu dibutuhkan keseimbangan antara daya dukung lingkungan dengan pemanfaatan lahan yang ada. Penelitian ini bertujuan untuk menentukan status daya dukung lingkungan berbasis neraca lahan eksisting serta untuk mengetahui status neraca lahan pada
\end{abstract}


tahun 2031, yaitu menggunakan metode deskriptif kuantitatif dengan cara mendiskripsikan hasil perhitungan untuk mendapatkan status neraca lahan. Perhitungan ketersediaan dan kebutuhan lahan diproyeksikan dengan tujuan untuk mengetahui jumlah ketersediaan dan kebutuhan lahan pada tahun 2031. Proses simulasi dibuat dengan cara memproyeksikan jumlah penduduk sampai tahun 2031 dengan menggunakan metode aritmatik. Hasil ketersediaan lahan dan kebutuhan lahan kemudian dibandingkan untuk mendapatkan status neraca lahan. Kecamatan Praya Barat memiliki total nilai produksi sebesar Rp 3.965.659.613.333,34, produktivitas beras sebesar $3251 \mathrm{Kg} / \mathrm{Ha}$; dengan harga beras $\mathrm{Rp} 8000,00 \mathrm{Kg}$, didapatkan hasil ketersediaan lahan eksisting sebesar 152.478,03 Ha. Analisis kebutuhan lahan menunjukkan bawa total nilai kebutuhan lahan eksisting sebesar 23.120,82 Ha dengan rincian jumlah penduduk tahun 2018 sebanyak 75.166 jiwa, dan kebutuhan hidup layak (KHL) sebesar 0,31 Ha/kapita. Status neraca lahan eksisting Kecamatan Praya Barat adalah surplus dengan selisih 129.357,21 Ha. Perhitungan daya dukung lingkungan basis neraca lahan pada tahun 2031 menggunakan ketersediaan lahan eksisting, yaitu sebesar 152.478,03 Ha, sedangkan perhitungan kebutuhan lahan menggunkan jumlah penduduk (N) tahun 2031 sebanyak 88.285 jiwa. Didapatkan Kebutuhan lahan tahun 2031 sebesar 27.156,04 Ha. Status daya dukung neraca lahan Kecamatan Praya Barat pada tahun 2031 masih surplus dengan selisih 125.321,99 Ha. Status surplus menunjukkan bahwa ketersediaan lahan masih dapat mencukupi kebutuhan produk hayati masyarakat setempat.

Kata kunci: daya dukung lingkungan; neraca lahan

\section{PENDAHULUAN}

\section{Latar Belakang}

Daya dukung lingkungan berbasis neraca lahan mengarah pada bagaimana menjaga ketersediaan serta kebutuhan produksi pangan pada suatu daerah. Perubahan penggunaan lahan dan meningkatnya jumlah populasi penduduk memberikan dampak besar dalam memenuhi kebutuhan baik dalam penggunaan lahan pertanian, kebutuhan pangan, dan pemukiman (Faroh, et al., 2020). Penurunan kulitas lingkungan mengakibatkan perbaikan rencana pengembangan pembangunan menjadi suatu hal yang mutlak untuk segera di wujudkan dalam upaya mengurangi laju penurunan pembangunan pertanian (Hartawan dan Ruwaidah, 2020). Pembangunan pertanian dalam hal ini ketersediaan pangan memiliki tantangan yaitu menurunya produktivitas lahan serta sumber daya alam terus menurun, sehingga perlu dilestarikan (Fauzi, et al., 2018). Menurut Zhang, et al. (2020), peningkatan populasi tingkat wilayah merupakan masalah penting karena populasi berpengaruh terhadap perubahan lingkungan dan sumber daya lahan yang tersedia.
Beberapa wilayah di Kabupaten Lombok Tengah beralih fungsi menjadi lahan pariwisata dan pemukiman, dikarenakan Nusa Tenggara Barat (NTB) khususnya Kabupaten Lombok Tengah ditetapkan dalam pembangunan Kawasan Ekonomi Khusus (KEK) yang bergerak di bidang pengembangan pariwisata. Alih fungsi lahan di kabupaten Lombok tengah terus bertambah akibatnya lahan pertanian makin berkurang, dengan rata-rata pengurangan lahan sebesar $10 \mathrm{Ha}$ pertahun dalam kurun waktu 10 tahun dari total lahan pertanian produktif saat ini yaitu $50,000 \mathrm{Ha}$ (Rosanti, 2020). Salah satu penyebab utama terjadinya alih fungsi lahan ini adalah pesatnya perkembangan pembangunan disektor pariwisata, sehingga sektor pendukung seperti perhotelan, perumahan, ruko, dibangun di atas lahan pertanian produktif.

Kecamatan Praya Barat merupakan salah satu kecamatan yang berada dalam wilayah kabupaten Lombok Tengah. Kecamatan Praya Barat berada di wilayah selatan yang berbatasan langsung dengan Samudra Indonesia yang artinya memiliki garis pantai yang panjang. Pengembangan sektor pariwisata berdampak langsung 
terhadap pembangunan. Keberadaan Bandara International Lombok (BIL) memberikan pengaruh besar sebagai pintu gerbang masuknya pengunjung international maupun domestik. Besarnya permintaan lahan untuk menunjang pembanguan pariwisata seperti perumahan, perhotelan, tempat rekresai, infrastruktur jalan, ruko, dan fasilitas lainya sangat berkembang di Kecamatan Praya Barat.

Alih fungsi lahan menuju Sektor parawisata memberikan dampak yang besar terhadap ketersediaan dan kebutuhan lahan. Ini menjadi tantangan yang harus dipenuhi agar sektor pariwisata semakin maju dan pemenuhan kebutuhan pangan masyarakat terus tepenuhi. Menurut Putra, et al. (2016), wilayah dikatakan memiliki ketahanan pangan yang baik apabila pangan tersedia, bermutu baik, rakyat dapat membeli dengan harga terjangkau, dan rakyat tidak harus tergantung secara mutlak kepada sumbersumber pangan wilayah lain. Menurut Rahadi, et al. (2018) dan Swiader, et al. (2020), upaya penilaian suatu wilayah dalam mengukur produktivitas Biocapacity dan kemampuan penyediaan pangan secara mandiri adalah dengan melakukan penilaian daya dukung lingkungan berbasis neraca lahan. Pada penelitian ini tidak menghitung atau menggunakan komoditas impor dan ekspor dikarenakan hanya fokus pada beberapa komoditas seperti komoditas pertanian, perkebunan, perikanan dan komoditas ternak. Oleh karena itu, dilakukan penelitian analsisis daya dukung lingkungan hidup berbasis neraca lahan untuk menjawab tantangan dan permasalahan yang terjadi, sehingga dapat menjadi acuan atau refrensi dalam mengambil kebijakan.

\section{Tujuan}

Penelitian ini bertujuan untuk menentukan status daya dukung lingkungan berbasis neraca lahan serta untuk mengetahui status neraca lahan pada tahun 2031 di daerah Kecamatan Praya Barat.

\section{METODE PENELITIAN}

\section{Waktu dan Tempat Penelitian}

Penelitian ini dilakukan di Kecamatan Praya Barat, Kabupaten Lombok Tengah, Provinsi Nusa Tenggara Barat atau pada titik koordinat $08^{\circ} 46^{\prime}-12^{\prime \prime}$ LS dan $116^{\circ} 13^{\prime}-48^{\prime \prime}$ BT pada bulan Agustus 2018.

\section{Alat dan Bahan}

Penelitian ini menggunakan peralatan dan data yang dijabarkan sebagai berikut:

1. Data primer didapatkan dengan cara survei harga beberapa komoditas produksi di pasar untuk mendapatkan data harga yang digunakan untuk menghitung total nilai produksi.

2. Data sekunder berupa data jumlah penduduk, data luas lahan produksi padi dan palawija, buah-buahan, sayuran, ternak, perikanan dan perkebunan.

3. Seperangkat PC (Personal Computer) yang dilengkapi dengan perangkat lunak (Software) Microsoft Word dan Microsoft Excel.

\section{Metode}

Metode deskriptif kuantitatif merupakan Metode yang digunakan. Analisis deskriptif kuantitatif bertujuan untuk mendiskripsikan hasil perhitungan dari data yang diperoleh Muttaqien, et al. (2020). Tahapan-tahapan dalam penelitian ini antara lain:

\section{Pengumpulan data}

Tahapan ini dilakukan dengan mengumpulkan beberapa data seperti data jumlah penduduk, data luas lahan produksi padi dan palawija, buah-buahan, sayuran, ternak, perikanan dan perkebunan yang didapatkan pada instansi terkait.

Data sekunder seperti data jumlah penduduk, populasi ternak, dan komoditas perkebunan diperoleh Dari Badan Pusat Statistika Kabupaten Lombok Tengah, data komoditas pertanian, palawija, buah-buahan dan sayuran diperoleh dari Dinas Pertanian Lombok Tengah, dan data perikanan diperoleh dari Dinas Kelautan dan Perikanan 
Kabupaten Lombok Tengah. Adapun data primer berupa data besaran harga komoditas yang diperoleh dengan cara survei pasar yang ada pada daerah studi.

\section{Analisis Ketersediaan Lahan}

Menurut Peraturan Menteri Negara Lingkungan Hidup No.17 Tahun 2009, ketersediaan lahan dihitung menggunakan metode perbandingan ketersediaan dan kebutuhan lahan seperti pada Persamaan 1.

$$
\mathrm{S}_{\mathrm{L}}=\frac{\Sigma\left(\mathrm{P}_{\mathrm{i}}-\mathrm{H}_{\mathrm{i}}\right)}{\mathrm{H}_{\mathrm{b}}} \times \frac{1}{\mathrm{P}_{\mathrm{tvb}}}
$$

Dimana:

SL $\quad=$ Ketersediaan lahan (ha)

$\mathrm{Pi} \quad=$ Produksi aktual tiap jenis komoditas (satuan tergantung jenis komoditas)

$\mathrm{Hi} \quad=$ Harga satuan tiap jenis komoditas (Rp/satuan)

$\mathrm{Hb}=$ Harga satuan beras $(\mathrm{Rp} / \mathrm{kg})$

Ptvb = Produktivitas beras $(\mathrm{kg} / \mathrm{ha})$

3.Analisis Kebutuhan Lahan

Analisis kebutuhan lahan ditentukan berdasarkan Peraturan Menteri Negara Lingkungan Hidup No.17 Tahun 2009, yaitu berdasarkan jumlah penduduk dan luas lahan hidup layak seperti pada Persamaan 2.

$\mathrm{D}_{\mathrm{L}}=\mathrm{N} \times \mathrm{KHL}$

Dimana:

DL = Total kebutuhan lahan setara beras (Ha)

$\mathrm{N} \quad=$ Jumlah penduduk (Jiwa)

KHLL = Luas lahan yang dibutuhkan untuk kebutuhan hidup layak per penduduk (Ha)

\section{Analisis Laju Pertumbuhan Penduduk}

Menurut Rahadi, et al. (2018), pertumbuhan penduduk dihitung menggunakan aritmatik seperti pada

Persamaan 3.

$\mathrm{Pn} \quad=\mathrm{Po}(1+\mathrm{r} \times \mathrm{n})$

Dimana:

$\mathrm{Pn} \quad=$ Jumlah penduduk pada tahun $\mathrm{n}$

Po = Jumlah penduduk pada tahun dasar

$\mathrm{r} \quad=$ Laju pertumbuhan penduduk

$\mathrm{n} \quad=$ Periode waktu antara tahun dasar dan tahun $\mathrm{n}$ (dalam tahun)

\section{Penentuan Status Neraca Lahan}

Menurut Peraturan Menteri Negara Lingkungan Hidup No.17 Tahun 2009, status daya dukung lingkungan neraca lahan ditentukan dengan cara membandingkan antara ketersediaan lahan $\left(\mathrm{S}_{\mathrm{L}}\right)$ dengan kebutuhan lahan $\left(D_{L}\right)$. Jika $S_{L}>D_{L}$, maka surplus dan jika $\mathrm{S}_{\mathrm{L}}<\mathrm{D}_{\mathrm{L}}$ maka defisit.

\section{HASIL DAN PEMBAHASAN}

\section{Komoditas Produksi}

Komoditas produksi Kecamatan Praya Barat antara lain meliputi padi dan palawija, buah-buahan, sayuran, ternak, perikanan dan perkebunan. Data Komoditas produksi didapatkan dari Dinas Pertanian dan Badan Pusat Statistik Kabupaten Lombok Tengah. Data produksi selanjutnya digunkan untuk menghitung nilai produksi aktual yang dikonversikan dengan masing-masing harga per komoditas.

\section{Komoditas Padi Dan Palawija}

Komoditas padi dan Palawija meliputi padi sawah, padi ladang, jagung kedelai, kacang hijau dan ubi kayu dengan total produksi Rp 356.852.333.333,33. Total harga didapatkan dari hasil perkalian antara produksi $(\mathrm{Kg})$ dengan harga satuan $(\mathrm{Kg} / \mathrm{Rp})$ tabel total nilai produksi komoditas padi dan palawija dapat dilihat pada Tabel 1 .

Tabel 1. Total nilai produksi padi dan palawija Kecamatan Praya Barat tahun 2018

\begin{tabular}{llrrrr}
\hline No & Komoditas & $\begin{array}{c}\text { Produksi } \\
(\text { Ton })\end{array}$ & \multicolumn{1}{c}{$\begin{array}{c}\text { Produksi } \\
(\mathrm{Kg})\end{array}$} & $\begin{array}{c}\text { Harga Satuan } \\
(\mathrm{Kg} / \mathrm{Rp})\end{array}$ & \multicolumn{1}{c}{$\begin{array}{c}\text { Total Harga } \\
(\mathrm{Rp})\end{array}$} \\
\hline 1 & Padi sawah & 46.006 & 46.006 .000 & 5.500 & $253.033 .000 .000,00$ \\
2 & Padi lading & 5.542 & 5.542 .000 & 5.500 & $30.481 .000 .000,00$ \\
3 & Jagung & 9.624 & 9.624 .000 & 3.833 & $36.892 .000 .000,00$ \\
4 & Kedelai & 4.047 & 4.047 .000 & 8.333 & $33.725 .000 .000,00$
\end{tabular}




\begin{tabular}{|c|c|c|c|c|c|}
\hline 5 & Kacang hijau & 42 & 42.000 & 14.000 & $588.000 .000,00$ \\
\hline 6 & Ubi kayu & 320 & 320.000 & 6.667 & $2.133 .333 .333,33$ \\
\hline & Nilai Produks & & & & 356.852.333.333,33 \\
\hline
\end{tabular}

Sumber: Data analisis (2020)

2. Komoditas Buah-Buahan

Komoditas buah-buahan Kecamatan Praya Barat meliputi beberapa jenis buahbuahan seperti jeruk, alpukat, mangga pisang, rambutan, papaya, jambu biji, nangka, belimbing dan semangka. Berbagai jenis buah tersebut memilki satuan harga yang berbeda. Total produksi komoditas buah-buahan sebesar Rp 2.750.896.666.666,67. Tabel total nilai produksi komoditas buah-buahan dapat dilihat pada Tabel 2.

\section{Komoditas Sayuran}

Komoditas sayuran Kecamatan

Praya Barat memilki beberapa jenis diantaranya bawang merah, cabai, kacang panjang, dan tomat. Total nilai produksi komoditas sayuran sebesar Rp 2.94.293.333.333,33. Tabel nilai produksi komoditas sayuran dapat dijabarkan pada Tabel 3 .

\section{Komoditas Ternak}

Komoditas ternak di Kecamatan Praya Barat meliputi sapi potong, kerbau, kuda, kambing, domba, ayam kampung, ayam pedaging, dan itik. Total nilai produksi komoditas ternak sebesar 317.116.200.000,00 Rupiah. Tabel nilai produksi komoditas ternak dapat dilihat pada tabel 4.

Tabel 2. Total nilai produksi komoditas buah-buahan Kecamatan Praya Barat tahun 2018

\begin{tabular}{llrrrr}
\hline No & Komoditas & $\begin{array}{c}\text { Produksi } \\
\text { (Ton) }\end{array}$ & \multicolumn{1}{c}{$\begin{array}{c}\text { Produksi } \\
(\mathrm{Kg})\end{array}$} & $\begin{array}{c}\text { Harga Satuan } \\
(\mathrm{Kg} / \mathrm{Rp})\end{array}$ & \multicolumn{1}{c}{$\begin{array}{c}\text { Total Harga } \\
(\mathrm{Rp})\end{array}$} \\
\hline 1 & Jeruk & 221 & 221.000 & 12.000 & $2.652 .000 .000,00$ \\
2 & Alpukat & 42 & 42.000 & 15.333 & $644.000 .000,00$ \\
3 & Mangga & 106.284 & 106.284 .000 & 23.000 & $2.444 .532 .000 .000,00$ \\
4 & Pisang & 1.790 & 1.790 .000 & 15.000 & $26.850 .000 .000,00$ \\
5 & Rambutan & 42 & 42.000 & 25.667 & $1.078 .000 .000,00$ \\
6 & Papaya & 2.202 & 2.202 .000 & 14.000 & $30.828 .000 .000,00$ \\
7 & Jambu biji & 1.346 & 1.346 .000 & 19.333 & $26.022 .666 .666,67$ \\
8 & Nangka & 4.769 & 4.769 .000 & 18.000 & $85.842 .000 .000,00$ \\
9 & Belimbing & 56 & 56.000 & 21.333 & $1.194 .666 .666,67$ \\
10 & Semangka & 17.120 & 17.120 .000 & 7.667 & $131.253 .333 .333,33$ \\
\hline & Nilai Produksi & & & & $\mathbf{2 . 7 5 0 . 8 9 6 . 6 6 6 . 6 6 6 , 6 7}$ \\
\hline
\end{tabular}

Sumber: Data analisis (2020)

Tabel 3. Total nilai produksi komoditas sayuran Kecamatan Praya Barat tahun 2018

\begin{tabular}{llrrrr} 
No & Komoditas & \multicolumn{1}{c}{$\begin{array}{c}\text { Produksi } \\
\text { (Ton) }\end{array}$} & \multicolumn{1}{c}{$\begin{array}{c}\text { Produksi } \\
(\mathrm{Kg})\end{array}$} & $\begin{array}{c}\text { Harga Satuan } \\
(\mathrm{Kg} / \mathrm{Rp})\end{array}$ & \multicolumn{1}{c}{$\begin{array}{c}\text { Total Harga } \\
(\mathrm{Rp})\end{array}$} \\
\hline 1 & Bawang merah & 450 & 450.000 & 23.667 & $10.650 .000 .000,00$ \\
2 & Cabai & 4.620 & 4.620 .000 & 56.667 & $261.800 .000 .000,00$ \\
3 & Kacang panjang & 3.065 & 3.065 .000 & 5.333 & $16.346 .666 .666,67$ \\
4 & Tomat & 970 & 970.000 & 5.667 & $5.496 .666 .666,67$ \\
\hline & Nilai Produksi & & & & $\mathbf{2 9 4 . 2 9 3 . 3 3 3 . 3 3 3 , 3 3}$ \\
\hline
\end{tabular}

Sumber: Data analisis (2020)

Tabel 4. Total nilai produksi komoditas ternak Kecamatan Praya Barat tahun 2018

\begin{tabular}{llrrr}
\hline No & Jenis Ternak & $\begin{array}{c}\text { Produksi } \\
\text { (Ekor) }\end{array}$ & $\begin{array}{c}\text { Harga Satuan } \\
\text { (Rp/Ekor) }\end{array}$ & \multicolumn{1}{c}{$\begin{array}{c}\text { Total Harga } \\
(\mathrm{Rp})\end{array}$} \\
\hline 1 & Sapi potong & 15.556 & 11.600 .000 & $180.449 .600 .000,00$ \\
2 & Kerbau & 4.139 & 12.500 .000 & $51.737 .500 .000,00$
\end{tabular}




\begin{tabular}{|c|c|c|c|c|}
\hline 3 & Kuda & 115 & 12.000 .000 & $1.380 .000 .000,00$ \\
\hline 4 & Kambing & 26.406 & 1.850 .000 & $48.851 .100 .000,00$ \\
\hline 5 & Domba & 293 & 1.600 .000 & $468.800 .000,00$ \\
\hline 6 & Ayam kampung & 32.8223 & 60.000 & $19.693 .380 .000,00$ \\
\hline 7 & Ayam pedaging & 55.500 & 58.000 & $3.219 .000 .000,00$ \\
\hline 8 & Itik & 15.2930 & 74.000 & $11.316 .820 .000,00$ \\
\hline & Nilai Produksi & & & $317.116 .200 .000,00$ \\
\hline
\end{tabular}

Sumber: Data analisis (2020

\section{Komoditas Perikanan}

Komoditas perikanan kecamatan paraya barat memilki beberapa jenis diantaranya ikan gabus, nila, karper, dan udang tawar. Total nilai produksi komoditas perikanan sebesar Rp 1.492.500.000,00. Tabel nilai produksi komoditas perikanan dapat dijabarkan pada Tabel 5.

\section{Komoditas Perkebunan}

Komoditas perkebuna kecamatan praya barat memilki beberapa jenis yaitu kelapa, kapuk, pinang, asam, jambu mete, jarak pagar, dan tembakau virginia. Total nilai produksi komoditas perkebunan sebesar $\mathrm{Rp}$ 1.492.500.000,00. Tabel nilai produksi komoditas perkebunan dapat dijabarkan pada Tabel 6 .

Tabel 5. Total nilai produksi komoditas perikanan kecamatan Praya Barat tahun 2018

\begin{tabular}{llrrrr}
\hline No & Komoditas & \multicolumn{1}{c}{$\begin{array}{c}\text { Produksi } \\
\text { (Ton) }\end{array}$} & \multicolumn{1}{c}{$\begin{array}{c}\text { Produksi } \\
(\mathrm{Kg})\end{array}$} & $\begin{array}{c}\text { Harga Satuan } \\
(\mathrm{Kg} / \mathrm{Rp})\end{array}$ & \multicolumn{1}{c}{$\begin{array}{c}\text { Total Harga } \\
(\mathrm{Rp})\end{array}$} \\
\hline 1 & Gabus & 7,50 & 7.500 & 14.000 & $105.000 .000,00$ \\
2 & Nila & 16,50 & 16.500 & 15.000 & $247.500 .000,00$ \\
3 & Karper & 13,80 & 13.800 & 25.000 & $345.000 .000,00$ \\
4 & Udang tawar & 31,80 & 31.800 & 25.000 & $795.000 .000,00$ \\
\hline & Nilai Produksi & & & & $\mathbf{1 . 4 9 2 . 5 0 0 . 0 0 0 , 0 0}$ \\
\hline
\end{tabular}

Sumber: Data analisis (2020)

Tabel 6. Total nilai produksi komoditas perkebunan Kecamatan Praya Barat tahun 2018

\begin{tabular}{llrrrr}
\hline No & Komoditas & $\begin{array}{c}\text { Produksi } \\
\text { (Ton) }\end{array}$ & $\begin{array}{c}\text { Produksi } \\
(\mathrm{Kg})\end{array}$ & $\begin{array}{c}\text { Harga Satuan } \\
(\mathrm{Kg} / \mathrm{Rp})\end{array}$ & \multicolumn{1}{c}{$\begin{array}{c}\text { Total Harga } \\
(\mathrm{Rp})\end{array}$} \\
\hline 1 & Kelapa & 701,73 & 701730 & 5.667 & $3.976 .470 .000,00$ \\
2 & Kapuk & 21,79 & 21790 & 5.000 & $108.950 .000,00$ \\
3 & Pinang & 5,18 & 5180 & 8.000 & $41.440 .000,00$ \\
4 & Asam & 3,00 & 3000 & 23.000 & $69.000 .000,00$ \\
5 & Jambu Mete & 131,70 & 131700 & 24.000 & $3.160 .800 .000,00$ \\
6 & Jarak Pagar & 6,49 & 6490 & 8.000 & $51.920 .000,00$ \\
7 & Tembakau Virginia & $1.900,80$ & 1900800 & 125.000 & $237.600 .000 .000,00$ \\
\hline & Nilai Produksi & & & & $245.008 .580 .000,00$ \\
\hline
\end{tabular}

Sumber: Data analisis (2020)

Nilai total produksi komoditas Kecamatan Praya Barat sebesar Rp 3.965.659.613.333,33 dengan rincian komoditas padi dan palawija memberikan nilai produksi terbesar, selanjutnya nilai produksi terendah yaitu komoditas perikanan. Dari masing-masing komoditas kemudian dijumlahkan nilai produksinya sehingga didaptkan total nilai produksi aktual. Total nilai produksi aktual akan digunakan untuk menghitung ketersediaan lahan.

\section{Analisis Pertumbuhan Penduduk}

Analisis pertumbuhan penduduk dilakukan untuk meproyeksikan jumlah penduduk pada tahun yang akan datang. Menurut Rahadi, et al. (2018) proses simulasi dilakukan untuk memproyeksikan jumlah penduduk dengan menggunakan 
aritmatik yang kemudian jumlah penduduk diakumulasikan dalam formula perhitungan kebutuhan lahan.

Analisis pertumbuhan penduduk pada Kecamatan Praya Barat menggunakan data jumlah penduduk 10 tahun terakhir yaitu dari tahun 2009-2018, kemudian data tersebut digunakan untuk mendapatkan nilai laju pertumbuhan penduduk (r). laju pertumbuhan penduduk kecamatan Praya barat sebesar 0,0134. Setelah mendapatkan nilai laju pertumbuhan penduduk, kemudian diproyeksikan jumlah penduduk sampai pada tahun 2031. Hasil proyeksi menggunakan metode aritmatik menunjukkan jumlah penduduk kecamatan pada tahun 2031 sebanyak 88.285 jiwa. Tabel 7 adalah hasil proyeksi jumlah penduduk Kecamatan Praya Barat pada tahun 2031.

\section{Ketersediaan Lahan}

Ketersediaan lahan merupakan luasan lahan yang tersedia untuk dimanfaatakan dalam menghasilkan produk hayati. Penentuan nilai ketersediaan lahan didasarkan pada total jumlah produksi aktual dari setiap komodiatas yang dihasilkan oleh suatu wilayah (Susanawati, et al., 2019). Kecamatan Praya Barat memilki produktivitas beras sebesar 3.251 $\mathrm{Kg} / \mathrm{Ha}$ dengan harga beras $\mathrm{Rp} 8.000 \mathrm{Kg}$, maka didapatkan hasil ketersediaan lahan di Kecamatan Praya Barat sebesar 152.478,03 Ha. Tabel nilai ketersediaan lahan pada Kecamatan Praya Barat dapat dijabarkan pada Tabel 8.

Tabel 7. Proyeksi jumlah penduduk Kecamatan Praya Barat dari tahun 2018-2031

\begin{tabular}{ccccc}
\hline Tahun & $\begin{array}{c}\text { Jumlah Penduduk } \\
\text { (Jiwa) }\end{array}$ & $\begin{array}{c}\text { Laju Pertumbuhan } \\
\text { Penduduk (r) }\end{array}$ & Tahun & $\begin{array}{c}\text { Jumlah Penduduk } \\
\text { (Jiwa) }\end{array}$ \\
\hline 2009 & 67.063 & & 2022 & 79.202 \\
2010 & 68.823 & & 2023 & 80.212 \\
2011 & 69.106 & & 2024 & 81.221 \\
2012 & 69.856 & 0.0134 & 2025 & 82.230 \\
2013 & 70.418 & & 2026 & 83.239 \\
2014 & 71.059 & & 2027 & 84.248 \\
2015 & 72.632 & & 2028 & 85.257 \\
2016 & 73.612 & & 2029 & 86.266 \\
2017 & 74.409 & & 2030 & 87.275 \\
2018 & 75.166 & & 2031 & 88.285 \\
\hline
\end{tabular}

Sumber: Data analisis (2020)

Tabel 8. Nilai ketersediaan lahan Kecamatan Praya Barat tahun 2018

\begin{tabular}{llll}
\hline $\begin{array}{l}\text { Faktor } \\
\text { Ketersediaan lahan }\left(\mathrm{S}_{\mathrm{L}}\right)\end{array}$ & Rumus & Nilai & Satuan \\
\hline Total nilai produksi & $\mathrm{S}\left(\mathrm{P}_{1} \times \mathrm{XH}_{1}\right)$ & $3.965 .659 .613 .333,33$ & $\mathrm{Rp}$ \\
$\begin{array}{l}\text { Harga beras } \\
\text { Total beras dari padi sawah dan }\end{array}$ & $\mathrm{H}$ & 8.000 & $\mathrm{Rp} / \mathrm{Kg}$ \\
$\begin{array}{l}\text { ladang } \\
\text { Luas panen padi }\end{array}$ & $\mathrm{P}_{\mathrm{b}}$ & 30.928 .800 & $\mathrm{Kg}$ \\
Produktivitas beras & $\mathrm{L}_{\mathrm{b}}$ & 9.514 & $\mathrm{Ha}$ \\
\hline $\begin{array}{l}\text { Ketersediaan Lahan } \\
\text { (Eksisting) }\end{array}$ & $\mathrm{Ptv}_{\mathrm{b}}=\mathrm{P}_{\mathrm{b}} / \mathrm{L}_{\mathrm{b}}$ & 3.251 & $\mathrm{Kg} / \mathrm{Ha}$ \\
\hline
\end{tabular}

Sumber: Hasil analisis dan perhitungan (2020)

\section{Kebutuhan Lahan}

Menurut Rahadi, et al. (2018) kebutuhan hidup layak per penduduk dibagi produktivitas beras total merupakan luas lahan yang dibutuhkan untuk kebutuhan layak per penduduk yaitu sebesar 1 Ton 
setara beras/kapita/ton, kebutuhan lahan didapatkan melalui perkalian antara kebutuhan hidup layak per penduduk dengan jumlah penduduk. Kecamatan praya barat pada tahun 2018 memilki jumlah penduduk sebesar 75.166 jiwa (Kecamatan
Praya Barat Dalam Angka 2018). Analisis kebutuhan lahan menunjukkan bahwa nilai ketersediaan lahan pada kecamatan praya barat sebesar 23.120,82 Ha. Tabel nilai kebutuhan lahan pada Kecamatan Praya Barat dapat dijabarkan pada Tabel 9.

Tabel 9. Nilai kebutuahan lahan Kecamatan Praya Barat tahun 2018

\begin{tabular}{llll}
\hline Faktor & Rumus & Nilai & Satuan \\
Kebutuhan lahan $\left(\mathrm{D}_{\mathrm{L}}\right)$ & & & \\
\hline Jumlah penduduk & $\mathrm{N}$ & 75.166 & Jiwa \\
Luas lahan hidup layak & $\mathrm{KHL}_{\mathrm{L}}=1$ ton $/ \mathrm{Ptv}_{\mathrm{b}}$ & 0,31 & $\mathrm{Ha}$ \\
\hline Kebutuhan Lahan (Eksisting) & $\mathrm{D}_{\mathrm{L}=\mathrm{Nx} \mathrm{KHL}}$ & $23.120,82$ & $\mathrm{Ha}$ \\
\hline
\end{tabular}

Sumber: Hasil analisis dan perhitungan (2020)

\section{Neraca Lahan Eksisting Kecamatan Praya Barat}

Perhitungan ketersediaan lahan dan kebutuahan lahan selanjutnya dibanding untuk mendapatkan status saya dukung lingkungan neraca lahan. Menurut Ishaq (2019), membandingkan nilai ketersediaan dengan kebutuhan lahan merupakan cara yang digunakan untuk mendapatkan status daya dukung lingkungan neraca lahan, metode ini sudah sesuai dengan peraturan Peraturan Menteri Negara Lingkungan Hidup No.17 Tahun 2009. Nilai total ketersediaan lahan sebesar 152.478,03 $\mathrm{Ha}$ dan kebutuhan lahan sebesar 23.120,82 Ha. hasil perbandingan menunjukkan bahawa status neraca lahan pada Kecamatan Praya Barat adalah surplus karna nilai ketersediaan lahan lebih besar dari pada nilai kebutuhan lahan dengan silisih perbandingan 129.357,21 Ha. Status surplus Kecamatan Praya Barat menunjukkan bahwa ketersediaan lahan masih dapat mencukupi kebutuhan produk hayati masyarakat setempat.

\section{Neraca Lahan Kecamatan Praya Barat Tahun 2031}

Perhitungan ketersediaan dan kebutuhan lahan diproyeksikan dengan tujuan untuk mengetahui jumlah ketersediaan dan kebutuhan lahan pada tahun 2031. Proses simulasi dibuat dengan cara memproyeksikan jumlah penduduk sampai tahun 2031 dengan menggunakan metode aritmatik. Hasil perhitungan daya dukung lingkungan basis neraca lahan menunjukkan bahwa ketersediaan lahan pada tahun 2031 menggunakan ketersediaan lahan eksisting yaitu sebesar 152.478,03 Ha, sedangkan perhitungan kebutuhan lahan pada tahun 2031 menggunakan jumlah penduduk (N) tahun 2031. Kebutuhan lahan mengalami peningkatan dari tahun 2018 yaitu sebesar 27.156,04 Ha, hasil ini kemudian dibandingkan untuk mendapatkan status daya dukung neraca lahan. Hasilnya adalah status daya dukung lingkungan neraca lahan pada tahun 2031 masih surplus atau belum terlampaui dengan selisih 125.321,99 Ha.

Meskipun terjadi peningkatan pertumbuhan penduduk, Kecamatan Praya Barat masih dalam kategori surplus, hal ini disebabkan oleh tingkat ketersediaan lahan pada wilayah tersebut masih cukup dan pertumbuhan penduduk yang stabil. Menurut Rahadi, et., al. (2018) peningkatan maupun penurunan jumlah penduduk akan mempengaruhi nilai kebutuhan lahan, sehingga dapat merubah status daya dukung neraca lahan wilayah tersebut. perubahan jumlah penduduk bisa saja disebabkan oleh fenomena perpindahan penduduk, penduduk cenderung pindah ke wilayah yang memiliki produksi komoditas tinggi, yang menyediakan lapangan pekerjaan yang lebih luas. Perhitungan status daya dukung lingkungan berbasis neraca lahan tahun 2031 di Kecamatan Praya Barat dapat dilihat pada Tabel 10. 
Tabel 10. Satus neraca lahan Kecamatan Praya Barat tahun 2031

\begin{tabular}{|c|c|c|c|}
\hline Faktor Ketersediaan lahan $\left(S_{L}\right)$ & Rumus & Nilai & Satuan \\
\hline Total nilai produksi & $\mathrm{S}\left(\mathrm{P}_{1} \times \mathrm{XH}_{1}\right)$ & $3.965 .659 .613 .333,33$ & $\mathrm{Rp}$ \\
\hline Harga beras & $\mathrm{H}_{\mathrm{b}}$ & 8.000 & $\mathrm{Rp} / \mathrm{Kg}$ \\
\hline Total beras dari padi sawah dan ladang & $\mathrm{P}_{\mathrm{b}}$ & 30.928 .800 & $\mathrm{Kg}$ \\
\hline Luas panen padi & $\mathrm{L}_{\mathrm{b}}$ & 9.514 & $\mathrm{Ha}$ \\
\hline Produktivitas beras & $\mathrm{Ptv}_{\mathrm{b}}=\mathrm{P}_{\mathrm{b}} / \mathrm{L}_{\mathrm{b}}$ & 3.251 & $\mathrm{Kg} / \mathrm{Ha}$ \\
\hline $\begin{array}{l}\text { Ketersediaan Lahan } \\
\text { (Eksisting) }\end{array}$ & $\begin{array}{l}\mathrm{S}_{\mathrm{L}}=\left(\mathrm{S}\left(\mathrm{P}_{1} \mathrm{xH}_{1}\right) /\right. \\
\left.\mathrm{H}_{\mathrm{b}}\right) \mathrm{x}\left(1 / \mathrm{Ptv}_{\mathrm{b}}\right)\end{array}$ & $152.478,03$ & $\mathrm{Ha}$ \\
\hline \multicolumn{4}{|l|}{ Kebutuhan Lahan $\left(D_{L}\right)$ Tahun 2031} \\
\hline Jumlah penduduk (Tahun 2031) & $\mathrm{N}$ & 88.285 & Jiwa \\
\hline Luas lahan hidup layak & $\mathrm{KHL}_{\mathrm{L}}=1$ ton$/ \mathrm{Ptv}_{\mathrm{b}}$ & 0,31 & $\mathrm{Ha}$ \\
\hline Kebutuhan Lahan & $\mathrm{D}_{\mathrm{L}}=\mathrm{Nx} \mathrm{KHL}_{\mathrm{L}}$ & $27.156,04$ & $\mathrm{Ha}$ \\
\hline \multicolumn{4}{|l|}{ Status Daya Dukung Lingkungan } \\
\hline Ketersediaan Lahan & $\left(\mathrm{S}_{\mathrm{L}}\right)$ & $152.478,03$ & $\mathrm{Ha}$ \\
\hline Kebutuhan Lahan & $\left(D_{L}\right)$ & $27.156,04$ & $\mathrm{Ha}$ \\
\hline Status & $\mathrm{S}_{\mathrm{L}}>\mathrm{D}_{\mathrm{L}}$ & SURPLUS & \\
\hline
\end{tabular}

Sumber: Hasil analisis dan perhitungan (2020)

\section{KESIMPULAN DAN SARAN}

\section{Kesimpulan}

Hasil analisis status daya dukung lingkungan berbasis neraca lahan di Kecamatan Praya barat adalah surplus dengan nilai ketersediaan lahan eksisting sebesar 15.2478,03 Ha, dan kebutuhan lahan eksisting sebesar 23.120,82 Ha dengan selisih 129.357,21 Ha. Terjadi peningkatan jumlah penduduk dari tahun 2018 sampai tahun 2031 hasil proyeksi jumlah penduduk Kecamatan Praya Barat tahun 2031 sebanyak 88.285 jiwa, sehingga status neraca lahan Kecamatan Praya Barat pada tahun 2031 masih surplus dengan rincian kebutuhan lahan sebesar 27.156,04 Ha. Status surplus Kecamatan Praya Barat menunjukkan bahwa ketersediaan lahan masih dapat mencukupi kebutuhan produk hayati masyarakat setempat.

\section{Saran}

Untuk mengetahui optimalisasi pemanfaatan sumber daya alam dalam daya dukung lingkungan, maka perlu dilakukan penelitian lanjutan dengan melakukan analsisis optimalisasi daya dukung lingkungan berbasis neraca lahan.

\section{UCAPAN TERIMA KASIH}

Ucapan terima kasih terutama ditunjukan kepada dosen pembimbing yang telah membantu menyelesaikan penelitian ini, serta kepada instansi-instansi terkait yang telah membantu dalam pelaksanaan penelitian ini.

\section{DAFTAR REFERENSI}

Badan Pusat Statistik. (2018). Kecamatan Praya Barat Dalam Angka 2018. BPS Kabupaten Lombok Tengah.

Faroh, E. P. I., Puspaningrani, F. C., Reinadova, G., Akbar, M. R., Anggraeni, N. D. S., Wildiyanti, O. S., Kafafa, U., \& Putri, R. F. (2020). Dynamic Changes Analysis of Land Resource Balance in North Maluku Province, Indonesia. ASEAN Journal on Science and Technology for Development, 37(2), 63-71.

Fauzi, F. R., Abdullah, S. H., \& Priyati, A. (2018). Evaluasi Kesesuaian Lahan untuk Komoditas Padi dengan Memanfaatkan Aplikasi Sistem Informasi Geografis (SIG) di Kabupaten Lombok Tengah. Jurnal 
Ilmiah Rekayasa Pertanian Dan Biosistem, 6(2), 131-140.

Hartwaan, T., \& Ruwaidah, E. (2020). Kajian Lingkungan Hidup Strategis (Klhs) Pada Rpjmd Kabupaten Lombok Tengah. Jurnal Sangkareang Mataram, 6(4), 30-38.

Ishaq, B. (2019). Daya Dukung Lingkungan Berbasis Keseimbangan Lahan Untuk Mendukung Program Geowisata Di Kawasan Karst Malang Selatan. Malang: Universitas Brawijaya.

Muttaqien, K., Haji, A. T. S., \& Sulianto, A. A. (2020). Analisis Kesesuaian Lahan Tanaman Padi Yang Berkelanjutan Di Kabupaten Indramayu. Jurnal Ilmiah Rekayasa Pertanian Dan Biosistem, 8(1), 48-57.

Putra, A. M., Rahadi, B., \& Susanawati, L. D. (2015). Penentuan daya dukung lingkungan berbasis neraca lahan tahun 2013 di Kota Baru. Jurnal Sumber Daya Alam Dan Lingkungan, 2(1), 1-6.

Rahadi, B., Anugroho, F., Nurlaelih, E. E., \& Lusiana, N. (2018). Daya Dukung
Dan Daya Tampung Untuk

Pengelolaan Lingkungan. Malang:

Universitas Brawijaya Press (Ub Press).

Rosanti, I. (2020). Alih Fungsi Lahan Pertanian Di Loteng Sulit Dibendung. Diakses dari https://insidelombok.id.

Susanawati, L. D., Widiatmono, B. R., \& Shandy, R. D. (2018). Analisis Neraca Lahan Terhadap Tata Ruang dan Wilayah (RTRW) Di Kabupaten Tuban. Jurnal Sumberdaya Alam Dan Lingkungan, 5(2), 10-17.

Swiader, M., Szewranski, S., \& Kazak, J. K. (2020). Świąder, M., Szewrański, S., \& Kazak, J. K. (2020). Environmental Carrying Capacity Assessment - the Policy Instrument and Tool for Sustainable Spatial Management. Frontiers in Environmental Science, 8(579838), 1-20.

Zhang, B., DeAngelis, D. L., \& Ni, W. M. (2021). Carrying Capacity of Spatially Distributed Metapopulations. Trends in Ecology and Evolution, 36(2), 164173. 